\title{
Correction to: The translation and psychometric assessment of the perception of empowerment in midwifery scale: the Persian version
}

Maryam Hajiesmaello ${ }^{1}$, Nourossadat Kariman ${ }^{2 *}$, Hamid Sharif $\mathrm{Nia}^{3}$, Giti Ozgoli², Sepideh Hajian², Shahin Bazzazian ${ }^{1}$ and Tahereh Mokhtarian-Gilani ${ }^{1}$

\section{Correction to: BMC Health Services Research (2020) 20:466 https://doi.org/10.1186/s12913-020-05326-y}

Following publication of the original article [1], the authors identified an error in the author name of Giti Ozgoli.

The incorrect author name is: Gity Ozgoli

The correct author name is: Giti Ozgoli

\begin{abstract}
Author details
'Student Research Committee, Department of Midwifery and Reproductive Health, School of Nursing and Midwifery, Shahid Beheshti University of Medical Sciences, Tehran, Iran. ${ }^{2}$ Midwifery and Reproductive Health Research Center, Department of Midwifery and Reproductive Health, School of Nursing and Midwifery, Shahid Beheshti University of Medical Sciences, Vali-e Asr Ave., Niayesh Intersection, Niayesh Complex, Tehran Postal Code: 1985717443, Iran. ${ }^{3}$ School of Nursing and Midwifery Amol, Mazandaran University of Medical Sciences, Sari, Iran.
\end{abstract}

Published online: 13 July 2020

\section{Reference}

1. Hajiesmaello $\mathrm{M}$, et al. The translation and psychometric assessment of the perception of empowerment in midwifery scale: the Persian version. BMC Health Serv Res. 2020;20:466. https://doi.org/10.1186/s12913-020-05326-y.

The original article can be found online at https://doi.org/10.1186/s12913020-05326-y.

*Correspondence: n_kariman@sbmu.ac.ir; n_kariman@yahoo.com

${ }^{2}$ Midwifery and Reproductive Health Research Center, Department of Midwifery and Reproductive Health, School of Nursing and Midwifery, Shahid Beheshti University of Medical Sciences, Vali-e Asr Ave., Niayesh Intersection, Niayesh Complex, Tehran Postal Code: 1985717443, Iran

Full list of author information is available at the end of the article

C The Author(s). 2020 Open Access This article is licensed under a Creative Commons Attribution 4.0 International License, which permits use, sharing, adaptation, distribution and reproduction in any medium or format, as long as you give appropriate credit to the original author(s) and the source, provide a link to the Creative Commons licence, and indicate if changes were made. The images or other third party material in this article are included in the article's Creative Commons licence, unless indicated otherwise in a credit line to the material. If material is not included in the article's Creative Commons licence and your intended use is not permitted by statutory regulation or exceeds the permitted use, you will need to obtain permission directly from the copyright holder. To view a copy of this licence, visit http://creativecommons.org/licenses/by/4.0/ The Creative Commons Public Domain Dedication waiver (http://creativecommons.org/publicdomain/zero/1.0/) applies to the data made available in this article, unless otherwise stated in a credit line to the data. 